\title{
DINAMIKA CADANGAN KARBON SISTEM AGROFORESTRI GMELINA (Gmelina arborea Roxb.) PADA HUTAN RAKYAT DI TASIKMALAYA DAN BANJAR, JAWA BARAT
}

\author{
CARBON STOCK DINAMICS OF GMELINA (Gmellina arborea Roxb.) BASED \\ AGROFORESTRY IN PRIVATE FOREST, TASIKMALAYA AND BANJAR DISTRICT, WEST \\ JAVA
}

\author{
M. Siarudin dan Yonky Indrajaya \\ Balai Penelitian dan Pengembangan Teknologi Agroforestry Ciamis \\ Jl. Raya Ciamis-Banjar km 4, Ciamis Jawa Barat \\ Email: msiarudin@yahoo.com
}

Diterima: 07 Maret 2017; direvisi: 21 Maret 2017; disetujui: 05 Mei 2017

\begin{abstract}
ABSTRAK
Penelitian ini bertujuan untuk mengukur cadangan karbon sistem agroforestri gmelina (Gmelina arborea Roxb.) dan dinamikanya pada beberapa daur pemanenan. Pengukuran cadangan karbon dilakukan pada bulan Maret - Oktober 2014 pada 17 lokasi di Kabupaten Tasikmalaya dan Kota Banjar, Provinsi Jawa Barat. Pengukuran cadangan karbon mengacu pada metode Rapid Carbon Stock Appraisal (RaCSA) dengan beberapa analisis tambahan. Dinamika cadangan karbon ditentukan berdasarkan daur biologi, dan daur teknis-1 (pemanenan pada diameter pohon $15 \mathrm{~cm}$ ) dan daur teknis-2 (pemanenan pada diameter pohon $20 \mathrm{~cm}$ ). Hasil penelitian menunjukkan karbon tersimpan pada tegakan agroforestri Gmelina di lokasi penelitian ini adalah rata-rata sebesar 170 ton/ha, terdiri dari 64 ton/ha karbon di atas permukaan tanah, dan 106 ton/ha. Daur optimal biologis (8 tahun) akan menghasilkan cadangan karbon maksimal pada akhir daur sebesar 15 ton/ha dengan rata-rata cadangan karbon sepanjang daur sebesar 7 ton/ha/tahun. Daur teknis-1 (14 tahun) dan daur teknis-2 (24 tahun) menghasilkan karbon maksimal pada akhir daur masing-masing sebesar 23 ton/ha dan 28 ton/ha, dengan rata-rata cadangan karbon sepanjang daur masing-masing sebesar 12 ton/ha/tahun dan 18 ton/ha/tahun berturutturut.

Kata kunci: daur biologi, daur teknis, gmelina, sistem agroforestri
\end{abstract}

\section{ABSTRACT}

This research aims at measuring carbon $(C)$ stock of gmelina (Gmelina arborea Roxb.) agroforestry system and its carbon diynamics due to several harvesting rotations. Observation was conducted during March - October 2014, on 17 plots in private forest, located in Tasikmalaya and Banjar District, West Java Province. The C-stock measurement followed Rapid Carbon Stock Appraisal Method (RaCSA) with some additional analysis. The dynamic of C-stock was measured based on biological rotation, technical rotation-1 (harvesting at tree diameter of $15 \mathrm{~cm}$ ) and technical rotation-2 (harvesting at tree diameter of $20 \mathrm{~cm}$ ). The result of the study shows that average of C-stock in gmelina agroforest stand is 170 ton/ha, consisted of 64 ton/ha above ground $C$ and 106 ton/ha below ground C. Biological rotation (8 years) results in maximum $C$-stock of 15 ton/ha at harvesting time, while the time averaged-C stock is 7 ton/ha/year.Technical rotation-1(14 years) and technical rotation-2 (24 years) result in maximum C-stock of 23 ton/ha and 28 ton/ha respectively, while the time averaged-C-stock are 12 ton/ha/year and 18 ton/ha/year respectively.

Keywords: agroforestry system, biological rotation, gmelina, technical rotation

\section{PENDAHULUAN}

Gmelina (Gmelina arborea Roxb.) atau yang dikenal sebagai jati putih dalam dunia perdagangan, adalah salah satu jenis yang banyak dibudidayakan di lahan masyarakat. Jenis ini dipilih karena cepat tumbuh, dikenal teknik budidayanya, dapat dipanen dengan daur pendek, karakteristik kayunya yang baik, dan memiliki nilai ekonomi yang baik (Riyanto et al., 2013; Roque and Fo, 2007; Lauridsen and Kjaer, 2002). Gmelina berdiameter kecil dapat dipanen pada umur 7 - 10 tahun dengan harga yang bersaing dengan jenis cepat tumbuh lainnya seperti Sengon (Roshetko et al., 2004). Kayu gmelina berwarna putih, tidak ada perbedaan yang jelas antara warna kayu gubal dan teras (Richter and Dallwitz, 2000), memiliki sifat kisaran berat jenis 0,33 - 0,51 dengan kelas awet V dan kelas kuat IV (Seng, 1990). Kayu gmelina umumnya dimanfaatkan sebagai bahan baku konstruksi ringan, pulp dan kertas, furniture, peti kemas, kerajinan kayu 
dll. (Idris et al., 2008; Soerianegara and Lemmens, 1994; Alrasjid dan Widiarti, 1992).

Penanaman gmelina di Tasikmalaya, Jawa Barat dan sekitarnya, menjadi salah satu program pengembangan hutan rakyat yang didukung pemerintah daerah setempat melalui pemberian bantuan bibit kepada petani. Petani seringkali menanam jenis gmelina dalam sistem agroforestri dengan tanaman musiman seperti kapulaga, cabai, jagung, dll.

Sistem penggunaan lahan dengan pola agroforestri pada hutan rakyat selain memiliki berbagai manfaat ekonomi langsung untuk masyarakat, juga memiliki manfaat jasa lingkungan seperti penyerapan karbon. Sistem agroforestri telah dikembangkan baik di negara berkembang maupun di negara maju untuk mengurangi laju emisi karbon (Nair et al., 2009).

Penelitian mengenai cadangan karbon sistem agroforestri pada hutan rakyat di Indonesia telah dilakukan dengan hasil yang bervariasi. Sebuah studi yang cukup komprehensif pada beberapa pola penggunaan lahan di Indonesia menunjukkan bahwa pola agroforestri dapat menyimpan karbon antara 17 114 ton/ha (Swallow et al., 2007). Penelitian di Lampung menunjukkan bahwa total karbon tersimpan di pekarangan pada semua pool karbon berkisar antara 56 - 174 ton/ha dengan rata-rata sebesar 107 ton/ha (Roschetko et al., 2002). Beberapa hasil penelitian lainnya menunjukkan rata-rata dan kisaran karbon di atas permukaan tanah yang bervariasi seperti agroforestri kebun campuran di Bekasi sebesar 62 ton/ha (Adinugroho et al., 2013); agroforestri kemenyan di Kabupaten Tapanuli Utara sebesar 51 66 ton/ha (Antoko, 2011); agroforestri di Langkat sebesar 57 - 63 ton/ha; dan agroforestri kebun campuran di Lampung sebesar rata-rata 43 ton/ha (Yuwono et al., 2012).

Cadangan karbon pada sistem agroforestri dapat berbeda tergantung struktur dan komponen penyusunnya (Albrecht and Kandji, 2003). Cadangan karbon juga akan ditentukan oleh umur tegakan (Hairiah et al., 2011), sehingga dinamika pada skala tegakan akan tergantung pada daur pemanenan yang diterapkannya. Informasi mengenai karbon tersimpan dan dinamikanya pada sistem agroforestri gmelina di hutan rakyat masih sangat terbatas. Penelitian ini memaparkan cadangan karbon sistem agroforestri gmelina serta dinamikanya pada beberapa model daur pemanenan. Diharapkan penelitian ini dapat menjadi informasi dasar untuk pengembangan agroforestri gmelina di hutan rakyat dalam mendukung mitigasi dan adaptasi perubahan iklim.

\section{METODE PENELITIAN}

Pengukuran cadangan karbon pada tegakan agroforestri gmelina dilakukan di 17 lokasi di Kecamatan Taraju, Kecamatan Sodonghilir dan Kecamatan Mangunreja Kabupaten Tasikmalaya, serta Kecamatan Pataruman dan Kecamatan Banjar, Kota Banjar, Provinsi Jawa Barat. Pemilihan lokasi didasarkan pada ketersediaan tegakan gmelina yang mewakili berbagai kelas umur. Total individu pohon yang diukur adalah sejumlah 1.058 pohon dari tegakan dengan umur 2 - 9 tahun.

Analisis biomasa dilakukan di laboratorium Balai Penelitian Teknologi Agroforestry, Ciamis, sedangkan analisis tanah dilakukan di Laboratorium Ilmu Tanah, Universitas Gadjah Mada, Yogyakarta.Penelitian dilakukan mulai bulan Maret Desember 2014.

\section{Metode Pengumpulan dan Analisis Data \\ 1. Pengukuran cadangan karbon}

Pengukuran cadangan karbon pada penelitian ini menggunakan prosedur RaCSA/Rapid Carbon Stock Appraisal (Hairiah et al., 2011). Pengukuran biomassa dilakukan pada 5 komponen, yaitu: biomassa pohon, biomassa tanaman bawah, nekromassa berkayu, nekromasa tidak berkayu (seresah) dan bahan organik organik tanah. Plot pengukuran terdiri dari plot utama berukuran $5 \mathrm{~m}$ x $40 \mathrm{~m}$, dan 6 sub plot berukuran $50 \mathrm{~cm}$ x $50 \mathrm{~cm}$ dalam setiap plot utama.

Pengukuran biomasa pohon dilakukan pada plot utama untuk pohon dengan diameter setinggi dada (diameter at breast height/DBH) $5-30 \mathrm{~cm}$. Jika di dalam plot terdapat pohon dengan DBH lebih dari 30 $\mathrm{cm}$, lebar plot utama diperluas menjadi $20 \mathrm{~m}$ x $100 \mathrm{~m}$ untuk mengukur pohon-pohon dengan DBH $>30 \mathrm{~cm}$ tersebut. Setiap pohon dalam plot pengukuran dicatat jenisnya dan diukur DBH. Jenis pohon dari famili Arecaceae (palm) diukur juga tinggi pohonnya karena dipersyaratkan dalam persamaan allometrik perhitungan biomassa.Biomassa di atas permukaan tanah per pohon dihitung dengan persamaan allometrik umum Chave et al. (2005):

$A G B=\rho \times \exp (-1,499+2,148 D+$ $\left.0,207(\ln D)^{2}-0,028(\ln D)^{3}\right)$

dimana $\rho$ merupakan kerapatan kayu, dan $D$ merupakan DBH (dalam cm). Data kerapatan kayu $\rho$ yang digunakan dalam perhitungan persamaan (1) merujuk pada data berat jenis Global Wood Density Database (Zanne et al., 2009) atau Seng (1990). Kandungan karbon diasumsikan sebesar 0,47 dari berat biomassanya (IPPC, 2006). Kandungan karbon 
akar diperhitungkan sebagai $20 \%$ dari kandungan

karbon di atas tanah (IPPC, 2006).

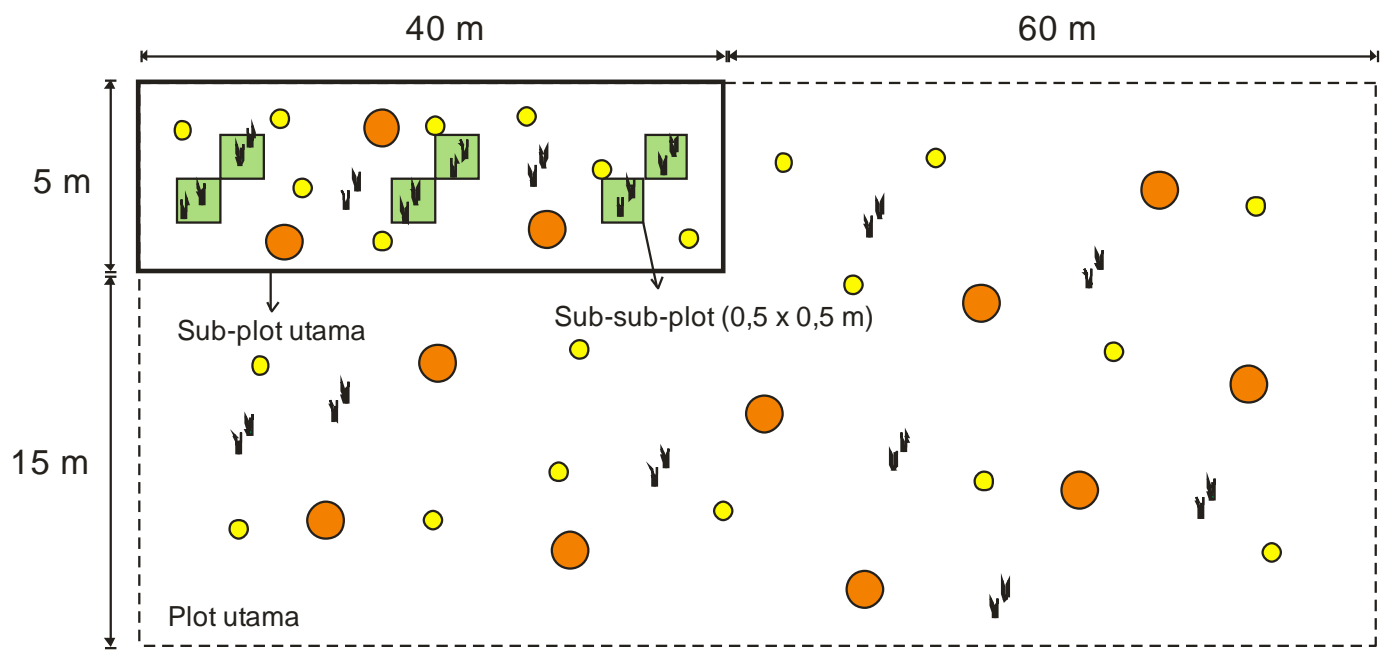

Pohon besar $(\mathrm{dbh}>30 \mathrm{~cm})$ di dalam atau di luar sub-plot utama

- Pohon dengan dbh 5 - $30 \mathrm{~cm}$ di dalam atau di luar sub-plot utama

V Pohon dengan $\mathrm{dbh}<5 \mathrm{~cm}$ adalah bagian dari tumbuhan bawah

Sub-sub-plot untuk pengambilan contoh tumbuhan bawah dan seresah

Gambar 1. Plot pengukuran cadangan karbon dan struktur tegakan agroforestri gmelina (sumber: diadaptasi dari Hairiah et al., (2011))

Pengukuran nekromasa berkayu dilakukan pada plot yang sama dengan pengukuran pohon. Nekromasa berkayu dapat berupa pohon yang mati berdiri, tunggul pohon bekas tebangan/pohon roboh, atau batang pohon mati yang rebah. Pengukuran nekromassa dengan diameter 5 - $30 \mathrm{~cm}$ dilakukan pada plot $5 \mathrm{~m}$ x $20 \mathrm{~m}$, dan nekromasa berdiameter lebih dari $30 \mathrm{~cm}$ diukur pada plot $20 \mathrm{~m}$ x $100 \mathrm{~m}$. Setiap nekromasa yang ditemukan diukur volumenya (dengan mengukur diameter dan tinggi atau panjang batang) serta diukur tingkat kelapukannya. Sampel sejumlah sekitar 300 gram diambil untuk diukur berat keringnya di laboratorium.

Pengukuran biomassa tumbuhan bawah dan nekromasa tidak berkayu (seresah) dilakukan pada sub plot $50 \mathrm{~cm}$ x $50 \mathrm{~cm}$. Tumbuhan bawah dan nekromasa tidak berkayu yang diambil dari sub plot ditimbang sebagai berat basah, dan kemudian diukur berat keringnya di laboratorium.

Sampel tanah untuk pengukuran kandungan $\mathrm{C}$ organik tanah dilakukan pada sub plot yang sama dengan pengukuran biomassa tumbuhan bawah dan nekromasa. Jenis sampel tanah yang diambil adalah sampel tanah terganggu untuk mengukur kandungan C organik tanah, dan sampel tanah tidak terganggu untuk mengukur berat isi (BI) tanah. Pengambilan sampel tanah terganggu dan tidak terganggu dilakukan pada 3 kedalaman, yaitu kedalaman $0-10 \mathrm{~cm}, 10-20 \mathrm{~cm}$ dan $20-30 \mathrm{~cm}$.

\section{Pengukuran dinamika cadangan karbon}

Dinamika cadangan karbon yang dihitung adalah dinamika cadangan karbon di atas permukaan tanah sepanjang daur gmelina. Penentuan dinamika cadangan karbon dilakukan dengan memperhitungkan estimasi volume pohon gmelina pada setiap kelas umur. Volume pohon pada setiap kelas umur ditentukan dengan menggunakan model hubungan antara diameter setinggi dada (DBH) dan tinggi total pohon terhadap umur pohon, yaitu (Siarudin et al., 2015):

$D=4,006 A^{0,506}$

$H=3,519 \ln A+2,38$

dimana $D$ adalah DBH (dalam $\mathrm{cm}), H$ adalah tinggi total pohon (dalam m) dan $A$ adalah umur pohon (dalam tahun).

Volume pohon diperoleh dengan persamaan:

$V=\frac{1}{4} \pi D^{2} \times H \times F$

dimana $V$ merupakan volume pohon (dalam $\mathrm{m}^{3}$ ), $D$ merupakan DBH (dalam $\mathrm{cm}$ ), $H$ merupakan tinggi pohon (dalam m), dan $F$ merupakan faktor bentuk 
pohon (tidak memiliki satuan). Karena belum adanya studi tentang faktor bentuk pohon gmelina, faktor bentuk yang digunakan dalam penelitian ini adalah faktor bentuk pohon jabon, yaitu 0,47 (Krisnawati et $a l ., 2011)$ mengingat secara fisiologis pohon gmelina mirip dengan pohon jabon.

Volume total gmelina dalam tegakan ditentukan dengan memperhitungkan perkiraan total jumlah pohon gmelina per ha dalam satu tegakan dengan volume individu pohon pada persamaan-4. Estimasi jumlah pohon per ha diasumsikan dengan kepadatan awal 2500 dan tingkat kematian pohon diasumsikan sama dengan tingkat kematian pohon tegakan manglid, yaitu rata-rata $5 \%$ per tahun (Siarudin et al., 2014). Tingkat kematian pohon gmelina diasumsikan sama tiap tahun. Estimasi jumlah pohon per ha pada tahun ke- $t$ adalah:

$N_{t}=N_{t-1}(1-0,05)$

Cadangan karbon total gmelina dalam satu tegakan pada setiap kelas umur dihitung dengan persamaan:

$C=\rho V \times 0,47$

dimana $C$ adalah cadangan karbon total dalam tegakan Gmelina (dalam ton/ha), $\rho$ adalah kerapatan kayu Gmelina, yaitu 0,413 gr/ $\mathrm{cm}^{3}$ (Zanne et al., 2009), $V$ adalah volume total gmelina per hektar (dalam $\mathrm{m}^{3} / \mathrm{ha}$ ) dan 0,47 adalah kandungan karbon tersimpan dalam biomassa menurut IPCC (2006).
Daur pemanenan yang digunakan dalam perhitungan dinamika cadangan karbon adalah: 1) Daur biologis, yaitu tegakan akan dipanen ketika riap volume rata-rata tahunan/MAI (Mean Annual Increment) sama dengan riap volume tahunan berjalan/CAI (Current Annual Increment) (Amacher et al., 2009; Bettinger et al., 2009); 2) Daur teknis-1, yaitu tegakan akan dipanen saat pohon gmelina mencapai diameter $15 \mathrm{~cm}$; dan 3) Daur teknis-2, yaitu tegakan akan dipanen saat pohon gmelina mencapai diameter $20 \mathrm{~cm}$. Daur teknis berdasarkan persyaratan diameter tertentu didasarkan pada informasi yang didapatkan di lokasi penelitian.

\section{HASIL DAN PEMBAHASAN}

Cadangan Karbon Sistem Agrogforestri Gmelina

Hasil pengukuran menunjukkan bahwa karbon tersimpan pada hutan rakyat pola agroforestri Gmelina di lokasi penelitian ini adalah rata-rata sebesar 170 ton/ha (terdiri dari 64 ton/ha karbon di atas permukaan tanah, dan 106 ton/ha karbon di bawah permukaan tanah) dengan kisaran antara $89-236$ ton/ha. Nilai cadangan karbon total tersebut lebih tinggi dari cadangan karbon pada sistem agroforestri manglid (Magnolia champaca) di Kabupaten Tasikmalaya sebesar 144 ton/ha (Siarudin et al., 2014). Nilai kisaran cadangan karbon pada penelitian ini juga lebih tinggi dari agroforestri kopi di DAS Konto yang dilaporkan Kurniawan et al. (2010) dengan kisaran karbon total antara 99 - 111 ton/ha.

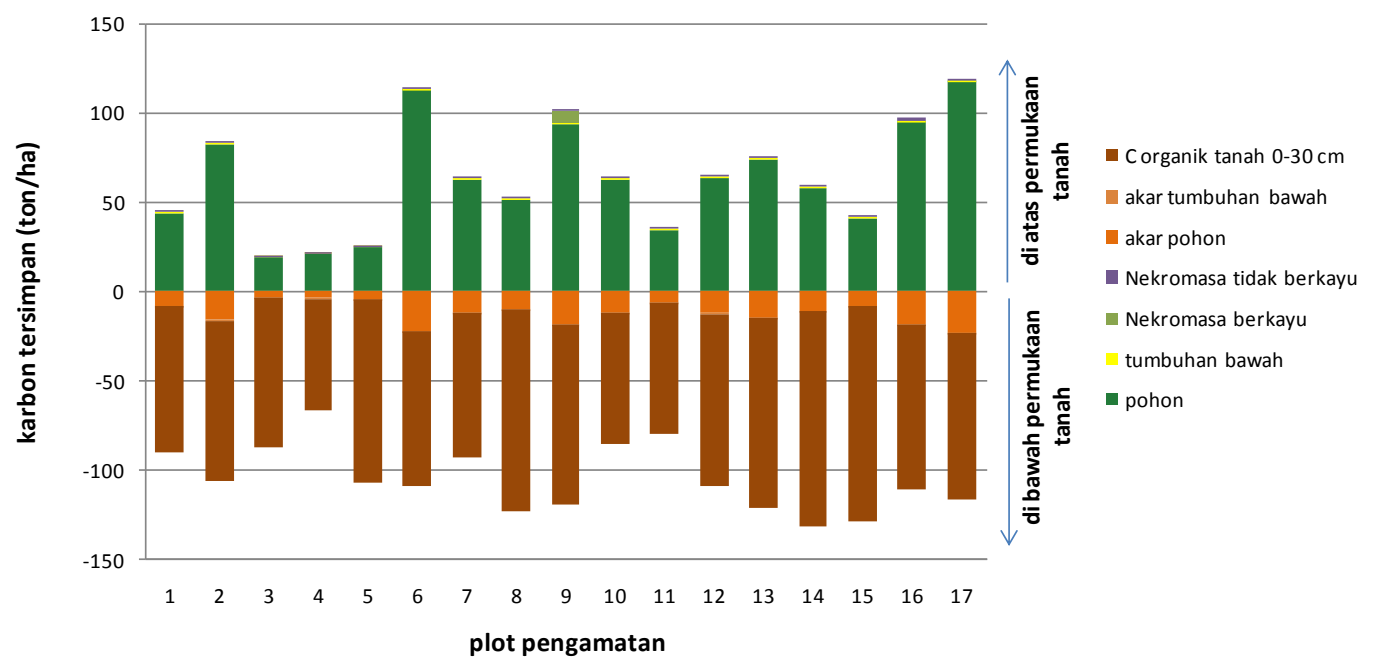

Gambar 2.Cadangan karbon pada hutan rakyat sistem agroforestri gmelina

Besaran cadangan karbon bervariasi antar lokasi, dimana karbon di atas permukaan tanah rata-rata adalah sebesar 64 ton/ha dengan kisaran antara 20 ton/ha sampai dengan 119 ton/ha. Nilai rata-rata karbon di atas permukaan tanah ini lebih tinggi dari sistem agroforestri manglid di Kabupaten Tasikmalaya yang hanya sebesar 44 ton/ha (Siarudin et al., 2014). Sistem agroforestri gmelina di Tasikmalaya juga menunjukkan kisaran cadangan karbon yang lebih tinggi di Jawa Barat menurut 
Rusulono (2006) dalam Tim Perubahan Iklim Badan Litbang Kehutanan (2010), yaitu antara 2 - 80 ton/ha. Beberapa hasil penelitian lainnya juga menunjukkan rata-rata dan kisaran karbon di atas permukaan tanah yang relatif setara seperti agroforestri kebun campuran di Bekasi sebesar 62 ton/ha (Adinugroho et al., 2013); agroforestri kemenyan di Kabupaten Tapanuli Utara sebesar 51-66 ton/ha (Antoko, 2011); agroforestri di Langkat sebesar 57 - 63 ton/ha. Sementara hasil penelitian di agroforestri kebun campuran di Lampung oleh Yuwono et al. (2012) menunjukkan nilai yang lebih rendah, yaitu rata-rata 43 ton/ha.

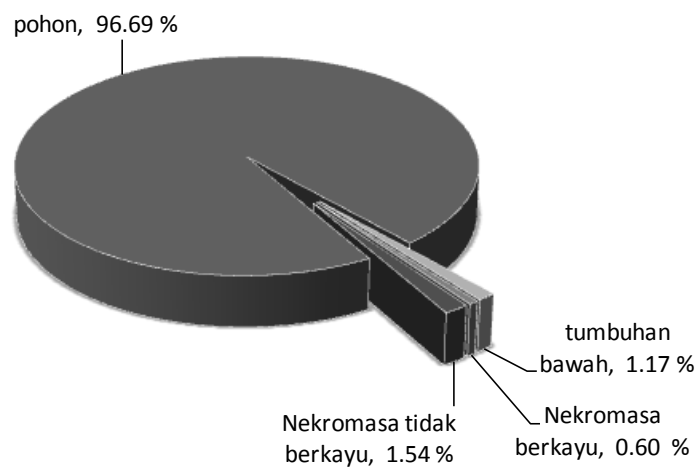

A

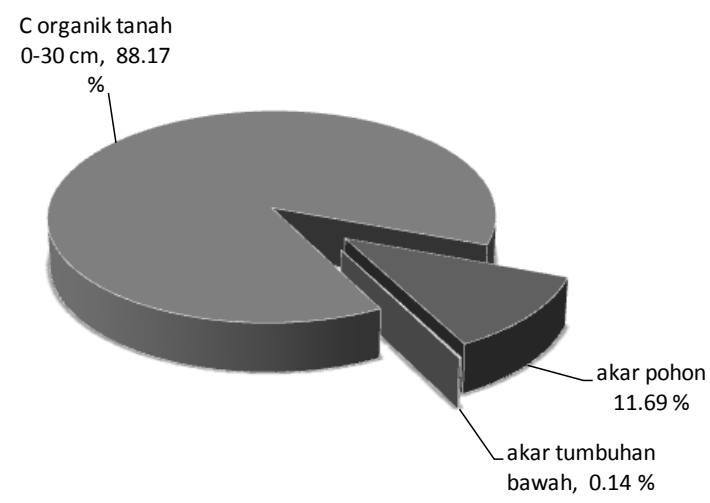

B

Gambar 3. (A) Persentase komponen penyusun karbon tersimpan di atas permukaan tanah; dan (B) Karbon tersimpan di bawah permukaan tanah

Gambar 3 menunjukkan bahwa carbon pohon menyumbang karbon total di atas permukaan tanah sebesar 96,7 \% (61,7 ton/ha) disusul bagian nekromasa tidak berkayu sebesar 1,5\% (1 ton/ha), biomasa tumbuhan bawah sebesar 1,2\% (0,8 ton/ha) dan nekromasa berkayu sebesar 0,6\% (0,4 ton/ha). Nilai tersebut sebanding dengan laporan Kurniawan et al. (2010) di DAS Kali Konto Hulu, Kabupaten Malang, dimana persentase karbon dari pohon, nekromasa dan tumbuhan bawah masing-masing sebesar 93,11\%, 5,31\% dan 1,54\%.

Karbon tersimpan di bawah permukaan tanah juga nampak bervariasi berkisar antara 67 - 132 ton/ha dengan rata-rata 106 ton/ha. Jika dibandingkan dengan sistem agroforestri manglid di Kabupaten Tasikmalaya (Siarudin et al., 2014), nilai rata-rata tersebut relatif setara yaitu sebesar 101 ton/ha. Sebagian besar karbon tersimpan tersebut ada dalam bentuk $\mathrm{C}$ organik tanah kedalaman $0-30 \mathrm{~cm}$ yaitu sebesar 88,2 \% (93 ton/ha), disusul akar pohon sebesar $11,7 \%$ (12 ton/ha) dan akar tumbuhan bawah sebesar $0,1 \%$ (0,2 ton/ha). Kisaran karbon tanah pada penelitian ini sebanding dengan laporan Nair et al. (2009) di mana C tanah pada kedalaman 0 - $45 \mathrm{~cm}$ pada agroforestri Psedotsuga sp. dan Trifolilum sp. di AS sebesar 95,89 ton/ha; demikian juga dengan karbon tanah pada kedalaman $0-40 \mathrm{~cm}$ pada agroforestri kopi ternaungi sebesar 92,27 ton/ha.

\section{Dinamika Cadangan Karbon Sistem Agroforestri Gmelina}

Dinamika cadangan karbon tegakan gmelina akan ditentukan oleh model pertumbuhan dan daur pemanenannya. Cadangan karbon maksimal pada akhir daur dan cadangan rata-rata sepanjang daur akan tergantung waktu pemanenannya, dimana cadangan karbon akan meningkat dengan semakin panjangnya daur pemanenan.

Gambar 4 menunjukkan bahwa nilai CAI dan MAI memiliki nilai yang sama pada umur pohon gmelina 8 tahun. Hal ini berarti daur optimal secara biologis pada tahun ke-8 setelah penanaman. Berdasarkan daur ini, pada saat pemanenan diperkirakan jumlah pohon 1.658 pohon/ha dengan total volume $78,2 \mathrm{~m}^{3} / \mathrm{ha}$. Pada akhir daur ini, didapatkan diameter rata-rata pohon $11,5 \mathrm{~cm}$ (Tabel 1). Jika pemanenan pohon gmelina mempertimbangkan diameter tertentu (daur teknis), maka daur optimal akan lebih panjang dari daur biologis ini. Jika pemanenan dilakukan pada saat diameter $15 \mathrm{~cm}$ (daur teknis-1), maka daur menjadi 14 tahun dengan perkiraan jumlah pohon 1219 pohon/ha dan volume total $122 \mathrm{~m} 3 / \mathrm{ha}$. Jika pemanenan dilakukan pada diameter $20 \mathrm{~cm}$ (daur teknis-2), maka daur menjadi 24 tahun dengan perkiraan jumlah pohon 730 pohon/ha dan volume total $146 \mathrm{~m}^{3} /$ ha. Selain daur biologis dan teknis, daur finansial dengan mempertimbangkan tambahan pendapatan yang diperoleh dari karbon menjadi lebih panjang tergantung dari harga karbonnya (Indrajaya \& Siarudin, 2015b). 
Tabel 1. Estimasi volume pohon dan cadangan karbon per hektar berdasarkan umur pohon

\begin{tabular}{|c|c|c|c|c|c|c|c|c|}
\hline $\begin{array}{l}\text { Umur } \\
\text { (Tahun) }\end{array}$ & $\begin{array}{l}\text { Populasi } \\
\text { (N/ha) }\end{array}$ & $\begin{array}{c}\mathrm{D} \\
(\mathrm{cm})\end{array}$ & $\begin{array}{l}\mathrm{H} \\
(\mathrm{m})\end{array}$ & $\begin{array}{c}\text { Volume } \\
\text { pohon } \\
\left(\mathrm{m}^{3}\right)\end{array}$ & $\begin{array}{c}\text { Volume } \\
\text { total } \\
\left(\mathrm{m}^{3} / \mathrm{ha}\right)\end{array}$ & $\begin{array}{c}\text { CAI } \\
\left(\mathrm{m}^{3} / \mathrm{ha}\right)\end{array}$ & $\begin{array}{c}\text { MAI } \\
\left(\mathrm{m}^{3} / \mathrm{ha}\right)\end{array}$ & $\mathrm{C}$ (ton/ha) \\
\hline 0 & 2.500 & - & - & - & - & - & - & - \\
\hline 1 & 2.375 & 4,01 & 2,38 & 0,001 & 3,35 & 3,35 & 3,35 & 0,7 \\
\hline 2 & 2.256 & 5,69 & 4,82 & 0,006 & 13,00 & 9,65 & 6,50 & 2,5 \\
\hline 3 & 2.143 & 6,98 & 6,25 & 0,011 & 24,12 & 11,12 & 8,04 & 4,7 \\
\hline 4 & 2.036 & 8,08 & 7,26 & 0,017 & 35,62 & 11,51 & 8,91 & 6,9 \\
\hline 5 & 1.934 & 9,04 & 8,04 & 0,024 & 47,01 & 11,38 & 9,40 & 9,1 \\
\hline 6 & 1.838 & 9,92 & 8,69 & 0,032 & 57,99 & 10,98 & 9,66 & 11,3 \\
\hline 7 & 1.746 & 10,72 & 9,23 & 0,039 & 68,41 & 10,42 & 9,77 & 13,3 \\
\hline 8 & 1.659 & 11,47 & 9,70 & 0,047 & 78,18 & 9,77 & 9,77 & 15,2 \\
\hline 9 & 1.576 & 12,18 & 10,11 & 0,055 & 87,25 & 9,07 & 9,69 & 16,9 \\
\hline 10 & 1.497 & 12,84 & 10,48 & 0,064 & 95,60 & 8,34 & 9,56 & 18,6 \\
\hline 11 & 1.422 & 13,48 & 10,82 & 0,073 & 103,21 & 7,62 & 9,38 & 20,0 \\
\hline 12 & 1.351 & 14,09 & 11,12 & 0,082 & 110,11 & 6,90 & 9,18 & 21,4 \\
\hline 13 & 1.283 & 14,67 & 11,41 & 0,091 & 116,30 & 6,19 & 8,95 & 22,6 \\
\hline 14 & 1.219 & 15,23 & 11,67 & 0,100 & 121,81 & 5,51 & 8,70 & 23,6 \\
\hline 15 & 1.158 & 15,77 & 11,91 & 0,109 & 126,67 & 4,86 & 8,44 & 24,6 \\
\hline 16 & 1.100 & 16,29 & 12,14 & 0,119 & 130,91 & 4,24 & 8,18 & 25,4 \\
\hline 17 & 1.045 & 16,80 & 12,35 & 0,129 & 134,56 & 3,65 & 7,92 & 26,1 \\
\hline 18 & 993 & 17,29 & 12,55 & 0,139 & 137,65 & 3,09 & 7,65 & 26,7 \\
\hline 19 & 943 & 17,77 & 12,74 & 0,149 & 140,21 & 2,57 & 7,38 & 27,2 \\
\hline 20 & 896 & 18,24 & 12,92 & 0,159 & 142,29 & 2,07 & 7,11 & 27,6 \\
\hline 21 & 851 & 18,70 & 13,09 & 0,169 & 143,90 & 1,61 & 6,85 & 27,9 \\
\hline 22 & 809 & 19,14 & 13,26 & 0,179 & 145,09 & 1,19 & 6,59 & 28,2 \\
\hline 23 & 768 & 19,58 & 13,41 & 0,190 & 145,88 & 0,79 & 6,34 & 28,3 \\
\hline 24 & 730 & 20,00 & 13,56 & 0,200 & 146,30 & 0,42 & 6,10 & 28,4 \\
\hline 25 & 693 & 20,42 & 13,71 & 0,211 & 146,38 & 0,08 & 5,86 & 28,4 \\
\hline 26 & 659 & 20,83 & 13,85 & 0,222 & 146,15 & $(0,23)$ & 5,62 & 28,4 \\
\hline 27 & 626 & 21,23 & 13,98 & 0,233 & 145,63 & $(0,52)$ & 5,39 & 28,3 \\
\hline 28 & 595 & 21,63 & 14,11 & 0,244 & 144,85 & $(0,78)$ & 5,17 & 28,1 \\
\hline 29 & 565 & 22,01 & 14,23 & 0,255 & 143,83 & $(1,02)$ & 4,96 & 27,9 \\
\hline 30 & 537 & 22,39 & 14,35 & 0,266 & 142,59 & $(1,24)$ & 4,75 & 27,7 \\
\hline
\end{tabular}

Sumber: Indrajaya \& Siarudin (2015a)

Keterangan: D = Diameter setinggi dada; $\mathrm{H}$ = Tinggi pohon; $\mathrm{CAI}=$ Riap volume tahun berjalan; $\mathrm{MAI}$ = Riap volume rata-rata tahunan; $\mathrm{C}=$ Cadangan karbon

Gambar 4 menunjukkan perbedaan dinamika cadangan karbon tegakan gmelina pada beberapa daur pemanenan. Daur optimal biologis (8 tahun) akan menghasilkan cadangan karbon maksimal pada akhir daur sebesar 15 ton/ha dengan rata-rata cadangan karbon sepanjang daur sebesar 7 ton/ha/tahun. Daur teknis untuk menghasilkan diameter minimal $15 \mathrm{~cm}$ akan menghasilkan karbon maksimal pada akhir daur sebesar 23 ton/ha dengan rata-rata cadangan karbon sepanjang daur sebesar 12 ton/ha/tahun. Sementara daur teknis untuk menghasilkan diameter minimal $20 \mathrm{~cm}$ akan menghasilkan karbon maksimal pada akhir daur sebesar 28 ton/ha dengan rata-rata cadangan karbon sepanjang daur sebesar 18 ton/ha/tahun. 


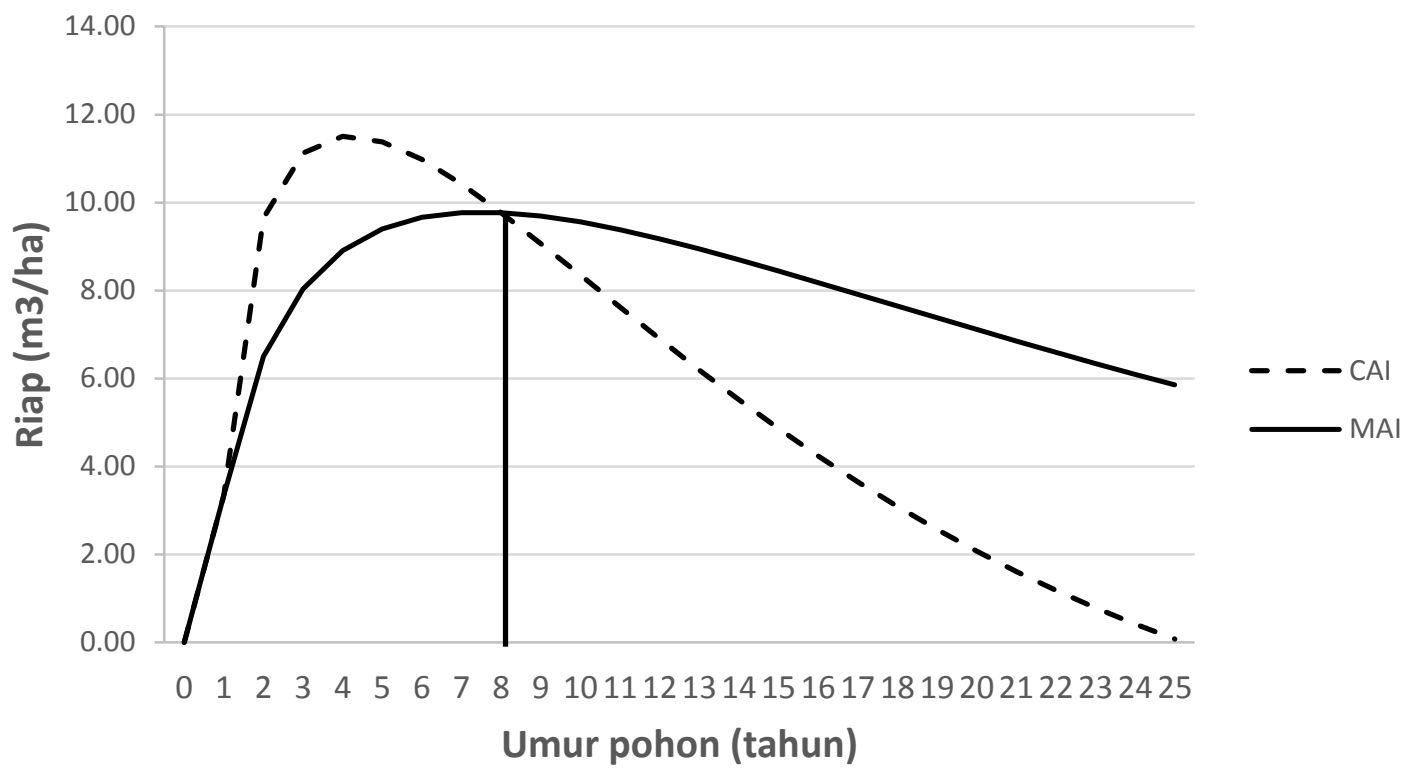

Gambar 4. Daur optimal biologis tegakan Gmelina

Sumber: Indrajaya \& Siarudin (2015a)

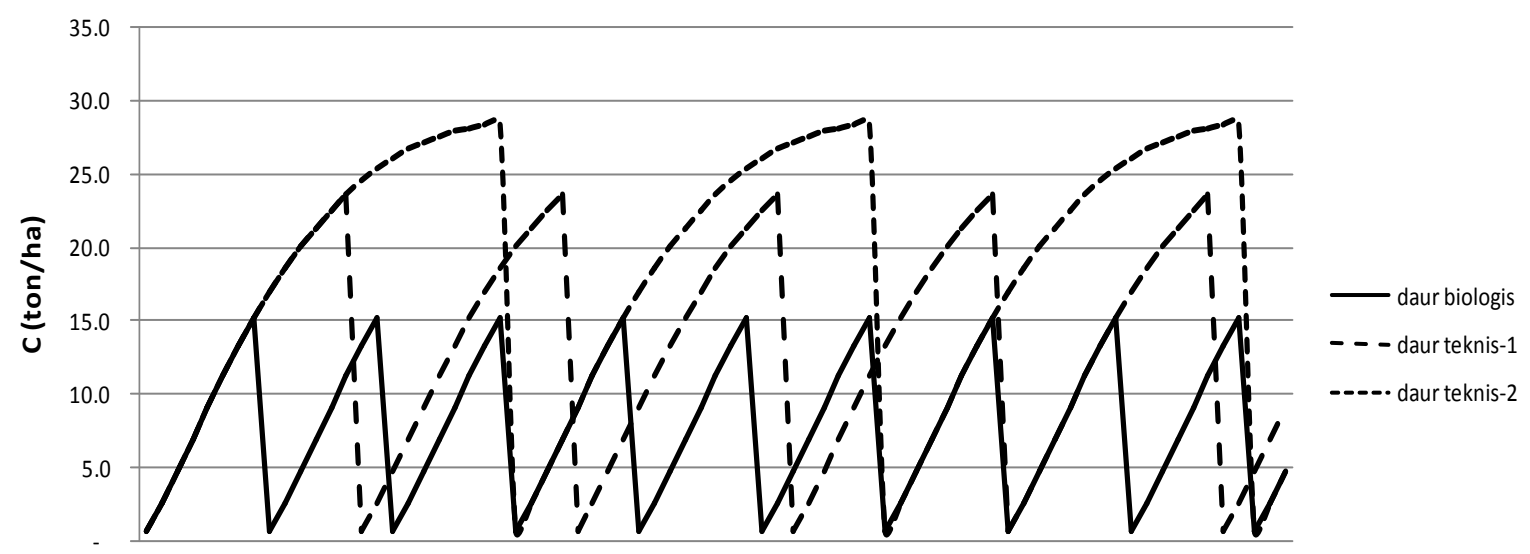

135779111315171921232527293133353739414345474951535557596163656769717375

tahun ke-

Gambar 4.Estimasi dinamika cadangan karbon di atas permukaan tanah sistem agroforestri Gmelina pada beberapa daur pemanenan

\section{KESIMPULAN}

Karbon tersimpan pada sistem agroforestri gmelina di lokasi penelitian ini adalah rata-rata sebesar 170 ton/ha, terdiri dari 64 ton/ha karbon di atas permukaan tanah, dan 106 ton/ha.

Daur optimal biologis (8 tahun) akan menghasilkan cadangan karbon maksimal pada akhir daur sebesar 15 ton/ha dengan rata-rata cadangan karbon sepanjang daur sebesar 7 ton/ha/tahun. Daur teknis untuk menghasilkan diameter minimal $15 \mathrm{~cm}$ akan menghasilkan karbon maksimal pada akhir daur sebesar 23 ton/ha dengan rata-rata cadangan karbon sepanjang daur sebesar 12 ton/ha/tahun. Daur teknis untuk menghasilkan diameter minimal $20 \mathrm{~cm}$ akan menghasilkan karbon maksimal pada akhir daur sebesar 28 ton/ha dengan rata-rata cadangan karbon sepanjang daur sebesar 18 ton/ha/tahun.

\section{SARAN}

Penerapan daur pemanenan gmelina perlu mempertimbangkan dinamika cadangan karbon yang dihasilkan, sebagai salah satu aspek lingkungan yang berkontribusi pada pengelolaan hutan rakyat yang berkelanjutan. 


\section{UCAPAN TERIMA KASIH}

Penulis mengucapkan terimakasih kepada Balai Penelitian dan Pengembangan Teknologi Agroforestry yang telah memfasilitasi kegiatan penelitian ini. Kami juga mengucapkan terimakasih kepada seluruh rekan-rekan teknisi yang telah membantu pengumpulan data di lapangan.

\section{DAFTAR PUSTAKA}

Adinugroho, W. C., Indrawan, A., Supriyanto, dan Arifin, H. S., (2013). Kontribusi agroforestry terhadap cadangan karbon di hulu DAS Kali Bekasi. Jurnal Hutan Tropis, 1(3), 242 - 249.

Albrecht, A. \& Kandji, S. T. (2003). Carbon sequestration in tropical agroforestry systems. Agriculture Ecosystems \& Environment, 99, 15 - 27.

Alrasjid, H., dan Widiarti, A. (1992). Teknik Penanaman dan Pemungutan Hasil Gmelina arborea. Petunjuk Teknis No 36, Pusat Penelitian dan Pengembangan Hutan. Bogor. 11 Hal.

Amacher, G. S., Ollikainen, M., Koskela, E. (2009). Economics of forest resources. MIT Press, Cambridge, Mass.

Antoko, B. S. (2011). Nilai insentif karbon hutan rakyat kemenyan berbasis voluntary carbon market di Kabupaten Tapanuli Utara. Thesis tidak diterbitkan, Institut Pertanian Bogor, Bogor.

Bettinger, P., Boston, K., Siry, J. P., dan Grebner, D. L. (2009). Forest Management and Planning. Burlington USA: Academic Press.

Chave, J., Andalo, C., Brown, S., Cairns, M. A., Chambers, J. Q., Eamus, D., Folster, H., Fromard, F., Higuchi, N., Kira, T., Lescure, J. P., Nelson, B. W., Ogawa, H., Puig, H., Riera, B., Yamakura, T. (2005). Tree allometry and improved estimation of carbon stocks and balance in tropical forests. Oecologia, 145, 87 99.

Hairiah, K., Ekadinata, A., Sari, R. R., Rahayu, S. (2011). Pengukuran cadangan karbon dari tingkat lahan ke bentang lahan. Bogor Indonesia: World Agroforestry Center,

Idris, M. M., Rachman, O., Pasaribu, R. A., Roliadi, H., Hadjib, N., Muslich, M., Jasni, Rulliaty, S., dan Siagian R. M, (2008). Petunjuk Praktis Sifat-Sifat Dasar Jenis Kayu Indonesia. Bogor: Pusat Penelitian dan Pengembangan Hasil Hutan.

Indrajaya, Y., \& Siarudin, M. (2015a). Daur tebang optimal hutan rakyat gmelina (Gmelina arborea Roxb.) di Tasikmalaya dan Banjar, Jawa Barat, Indonesia. Jurnal Penelitian Sosial Ekonomi Kehutanan, 12(2), 109 - 116.

Indrajaya, Y., \& Siarudin, M. (2015b). The effects of carbon payment on optimal rotation of Gmelina forests. Paper presented at the INAFOR 3, Bogor, Indonesia.

IPCC. (2006). IPCC Guideline 2006 Guidelines for national green house gas inventories. In. IPCC.

Krisnawati, H., Kallio, M., Kanninen, M. (2011a). Anthocephalus cadamba Miq.: Ekologi, Silvikultur, Produktivitas. Bogor: CIFOR.
Kurniawan, S., Prayogo, C., Widianto, Zulkarnain, M. T., Lestari, N. D., Aini, F. K., Hairiah, K. (2010). Estimasi Karbon Tersimpan di Lahan-lahan Pertanian di DAS Konto, Jawa Timur: RACSA (Rapid Carbon Stock Appraisal). Working paper 120. World Agroforestry Centre (ICRAF) Southeast Asia Program

Nair, P. K. R., Kumar, B. M., Nair, V. D. (2009). Agroforestry as a strategy for carbon sequestration. Journal of Plant Nutrition Soil Science, 172, 10 - 23.

Richter, H. G., and Dallwitz, M. J. (2000). Commercial timbers: descriptions, illustrations, identification, and information retrieval. In English, French, German, Portuguese, and Spanish. Version: 25th June 2009. http://delta-intkey.com/. Diakses pada tanggal 26 Januari 2015.

Riyanto, A. B., Patola, E., dan Siswadi. (2013). Uji Dosis Frekuensi Aplikasi Pupuk Urea terhadap Pertumbuhan Bibit Jati Putih (Gmelina arborea Roxb.). INNOFARM: Jurnal Inovasi Pertanian 12 (2), 1 - 13 .

Roschetko, J. M., Delaney, M., Hairiah, K., Purnomosidhi, P. (2002). Carbon stocks in Indonesian homegarden systems: can smallholder systems be targeted for increased carbon storage?. American Journal of Alternative Agriculture, 17, 1 - 11.

Roshetko, J. M., Mulawarman, Purnomosidhi, P. (2004). Gmelina arborea - a viable species for smallholder tree farming in Indonesia?. New Forest, 28, 207215.

Seng, O. D. (1990). Spesific Gravity of Indonesian Woods and Its Significance for Practical Use. Diterjemahkan oleh Suwarsono P.H. Pusat Penelitian dan Pengembangan Hasil Hutan. Bogor, Indonesia: Departemen Kehutanan Indonesia.

Siarudin, M., Indrajaya, Y., Badrunasar, A. (2015). Pemanfaatan lahan agroforestri untuk mendukung mekanisme REDD+. Laporan tidak diterbitkan, Balai Penelitian Teknologi Agroforestry, Badan Litbang Kehutanan, Ciamis.

Siarudin, M., Indrajaya, Y., Suhaendah, E., Badrunasar, A. (2014). Laporan Hasil Penelitian "Pemanfaatan Lahan Agroforestry untuk Mendukung Mekanisme REDD+". Laporan tidak diterbitkan, Balai Penelitian Teknologi Agroforestry, Badan Litbang Kehutanan, Ciamis.

Soerianegara, I., and Lemmens, R. H. M. J (eds). (1994). Plant Resources of South-East Asia (5): (1) Timber trees: Major Commercial Timbers. Prosea Foundation. Bogor. Indonesia

Swallow, B., Van Noordwijk, M., Dewi, S., Murdiyarso, D., White, D., Gockowski, J., Hyman, G., Budidarsono, S., Robiglio, V., Meadu, V., Ekadinata, A., Agus, F., Hairiah, K., Mbile, P. N., Sonwa, D. J., Weise, S. (2007). Opportunities for Avoided Deforestation with Sustainable Benefits. An Interim Report by the ASB Partnership for the Tropical Forest Margins. ASB Partnership for the Tropical Forest Margins, Nairobi, Kenya.

Tim Perubahan Iklim Badan Litbang Kehutanan. (2010). Cadangan karbon pada berbagai tipe hutan dan jenis tanaman di Indonesia. Bogor: Pusat Litbang 
Perubahan Iklim dan Kebijakan. Badan Litbang Kehutanan.

Yuwono, S. B, Hilmanto, R., dan Qurniati, R. (2012). Estimasi total penyerapan karbon tersimpan pada sistem agroforestri di Desa Sumber Agung untuk mendukung Rencana Aksi Nasional Gas Rumah Kaca. Seminar Agroforestri III.
Zanne, A. E., Lopez-Gonzalez, G., Coomes, D. A., Ilic, J., Jansen, S., Lewis, S. L., Miller, R. B., Swenson, N. G., Wiemann, M. C. and Chave, J. (2009). Global wood density database.Dryad. Identifier: http://hdl.handle.net/10255/dryad.235 
Jurnal WASIAN Vol.4 No.1 Tahun 2017:37-46 